\title{
A SIMULATION STUDY ON THE MANOEUVRABILITY OF A LARGE SIZE SEMITRAILER
}

\author{
Grzegorz Koszałka, Andrzej Zniszczyński \\ Faculty of Mechanical Engineering, Lublin University of Technology, Lublin, Poland
}

Submitted 27 January 2014; resubmitted 28 March 2014, 28 April 2014; accepted 5 January 2015; first published online 13 July 2015

\begin{abstract}
As part of a research project aimed at designing the structure of a new special-purpose multi-axle semitrailer for transporting large machines and equipment, a simulation study on the manoeuvrability of the semitrailer during its passage through a tight corner was performed. The aim of this study was to determine whether the semitrailer would meet the legal requirements regarding manoeuvrability after it has been implemented for production. The simulations were carried out using a specially designed spreadsheet. The spreadsheet enabled analysis of the movements of the wheels of the tractor-trailer combination, with the assumption that they roll without skidding; it also described changes in the steering angles of trailer wheels, as well as off-tracking and corner-cutting during turning. When the geometrical parameters of the tractor and trailer were changed, the spreadsheet allowed tracing their impact on the manoeuvrability of the whole combination. This paper presents the results of the simulations and points to the desired features of a semitrailer steering system that facilitate negotiating tight corners.
\end{abstract}

Keywords: semitrailer; articulated heavy vehicle; oversize transport; steering axle; steering system; corner cutting; outswinging.

\section{Introduction}

Traffic places increasing demands on drivers and vehicles. High traffic congestion and narrow streets with large numbers of turns and roundabouts require concentration on the part of the driver, but they are also a challenge to designers of modern steering systems in vehicles. Such systems should facilitate negotiation of turns with small radii and narrow road surface. Systems of this kind are particularly desirable in the case of long road vehicles consisting of a tractor unit and semitrailer. In combinations, there are usually two separate steering systems: the tractor and the trailer ones. While tractor steering systems can be considered as quite refined (Dixon 2009; Ormezowski 2008), even though research is still being done on their development (Gidlewski 2011; Hussain et al. 2005), their counterparts in trailers, especially long, multi-axial semitrailers, require further research and development, which are intensively conducted (Berjoza 2008; Bortoni-Anzures et al. 2008; Ding et al. 2013; He et al. 2010; Kharrazi et al. 2013; Odhams et al. 2011; Percy, Spark 2012; Rangavajhula, Tsao 2008).

The steering system of a long semitrailer, as a separate unit, should respond to the movements of the trac- tor, at the same time carrying out two tasks: it should ensure proper alignment of the wheels in a turn, which affects the parasitic losses connected with side slipping of the trailer wheels, and provide adequate trajectory of movement of the entire trailer behind the tractor so that it does not cause excessive corner cutting or out-swinging. Minor errors in steering the position of trailer wheels are unimportant. This is because pneumatic tyres can bend in the lateral direction. This allows all the wheels of the trailer to negotiate the same turn without a skid despite small deviations from the correct position. However, greater errors in steering the wheels result in skidding and increased tyre wear, as well as considerable load for the tractor unit and the structure of the semitrailer, especially in the case of a heavy and long one. This effect is dependent on the type of tyres, their profiles, the degree of inflation, the radius of the wheels, their load, as well as the surface of the road and its form (Liu, Caroux 2011). Unfortunately, both minor and greater errors in steering the position of wheels have an impact on the direction of movement of the trailer during a turn; this makes it very difficult to precisely determine the actual trajectory of the movements of the entire trailer (Tabatabaei Oreh et al. 2012).

Corresponding author: Grzegorz Koszałka

E-mail: g.koszalka@pollub.pl 
It is therefore important that designers developing semitrailer steering systems should take into account the optimal steering angle of the wheels in the different phases of negotiating a turn. It should be determined which of the geometric parameters of the trailer and its steering system facilitate the proper execution of the turning manoeuvre.

The analyses presented in this paper were performed to determine the possibility of meeting the legal requirements on the manoeuvrability of a tractor-trailer combination. They were used by Wielton Company (http://wielton.com.pl) to develop specific guidelines for designing a new oversize semitrailer.

\section{Assumption to the Semitrailer Design and Aim of the Work}

The presented simulation studies were carried out as part of a project whose aim was to design the structure of a new special semitrailer for transporting large machinery and equipment, and then implement it for production at Wielton Company. In addition to the work done on the steering system of the semitrailer, simultaneous research concerned the development of its support structure (Dębski et al. 2012) and the systems enhancing the safety of the vehicle and the payload (Koszałka, Olejnik 2012; Stokłosa et al. 2012) were conducted.

The semitrailer designed was to have a payload of 60 tonnes and Gross Vehicle Weight of 84 tonnes (24 tonnes supported by the fifth wheel and 60 tonnes on five axles). For functional reasons it was assumed that the main, low platform would have a length of $5.5 \mathrm{~m}$ and the length could be extended by at least $2 \mathrm{~m}$. The width of both the low and rear platforms should also be extended by $0.55 \mathrm{~m}$. For design and legal reasons the distance between axle lines was initially established to approximately $1.5 \mathrm{~m}$. It was also assumed that the design of the semitrailer should make it possible to couple it to a tractor unit with a maximum number of four axles (Fig. 1).

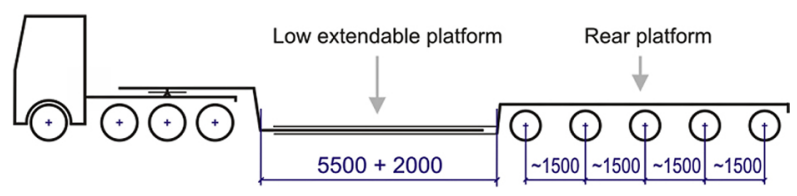

Fig. 1. Sketch of the analysed tractor-semitrailer combination
The semitrailer designed was to be a special purpose vehicle, so it did not have to comply with all standard requirements - Directive 96/53 (EC 1996), Commission Regulation (EU) No 1230/2012 (EU 2012). However, the manufacturer - Wielton Company decided that the semitrailer should meet German requirements specified in TÜV recommendations (Richtlinien für die Erteilung... 1993).

The aim of the analysis presented in this paper was to determine whether the semitrailer could meet the vehicle manoeuvrability criteria specified in TÜV guidelines (Table 1), and if those criteria could be met with one non-steerable axle (Richtlinien für die Erteilung... 1993). Applying a non-steerable axle would make the design simpler and improve the lateral performance of the semitrailer.

\section{Analysis of the Turn Manoeuvre of a Tractor-Semitrailer Combination}

To prevent side slipping of the wheels of a multi-axial semitrailer during the negotiation of a bend at low speed, when inertial forces can be neglected, the wheels should be turned to the angles for which the instantaneous direction of the linear displacement of the wheel and the principal plane of the wheel are congruent. This condition is satisfied if the extensions of all wheels cross at one point $\left(\mathrm{O}_{2}\right.$ in Fig. 2). Almost all standard two- or three-axial semitrailers are equipped with non-steerable axels. That means that the above condition cannot be

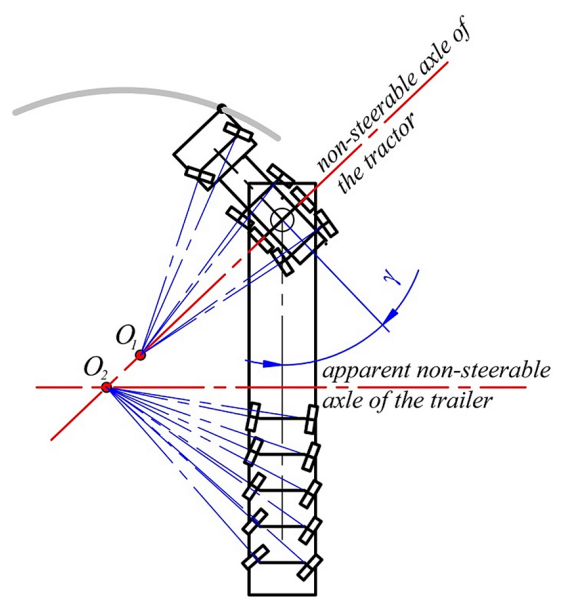

Fig. 2. The correct settings for the wheels of the tractor and the semitrailer during a turn

Table 1. Summary of requirements regarding tractor-trailer combinations negotiating a turn (Richtlinien für die Erteilung... 1993)

\begin{tabular}{|c|c|c|c|c|c|}
\hline Combination length $[\mathrm{m}]$ & Curve $\left[{ }^{\circ}\right]$ & Outer radius [m] & Inner radius [m] & Road space $[\mathrm{m}]$ & Max. rear out swing $[\mathrm{m}]$ \\
\hline$<17.5$ & 360 & 12.5 & 5.3 & 7.2 & 0.8 \\
\hline$>17.5$ and $\leq 20$ & 120 & 12.5 & 5.3 & 7.2 & 1.1 \\
\hline$>20$ and $\leq 23$ & 120 & 14 & 6.5 & 7.5 & $1.4^{*}$ \\
\hline$>23$ and $\leq 25$ & 120 & 14 & 6.0 & 8.0 & $1.4^{*}$ \\
\hline$>25$ and $\leq 27$ & 120 & 14 & 5.0 & 9.0 & $1.4^{*}$ \\
\hline
\end{tabular}

Note: * manual steering allowed. 
fulfilled and the unturned wheels of such semitrailers moving in a turn, especially a tight one, have to skid. Such tire scrubbing increases fuel consumption and tire wear and creates additional strain on the trailer body and on the road. To reduce these undesirable effects, a rearmost steerable axle is sometimes used, even in standard semitrailers. Usually a self-steering axle is used in which the wheels turn automatically under the influence of lateral tire forces.

In the case of heavy and long semitrailers with large distances between extreme axles, as investigated in the present paper, substantial tire side slipping/scrubbing is unacceptable, because it would create large crosswise forces acting on the frame, axles and wheels of the semitrailer. Therefore, positively steered axles and proper steering systems are applied in such semitrailers. The role of the steering system during low speed cornering is to provide the steering angles of the wheels which satisfy the conditions for ideal turning. At such a setting of the wheels and low speed of trailer on hard and smooth pavement, the side slipping of the wheels is small. It should be noted that during the test of manoeuvrability according to TÜV recommendations the tractor-trailer combination drives at a very low speed (Richtlinien für die Erteilung... 1993). Therefore, side slipping of the wheels was neglected in the theoretical investigation of the semitrailer manoeuvrability presented here.

An analysis of the positions of the wheels of a tractor-semitrailer combination negotiating a turn, assuming the wheels move without a skid, reveals the following regularities. In the tractor, in accordance with ideal steering geometry, protractions of the steerable wheel axle should intersect with the direction of the rear nonsteerable axle at one point $O_{1}$, creating an instant turning centre of the tractor (Fig. 2).

In the semitrailer, on the other hand, assuming that the axis of the tractor's fifth-wheel kingpin is positioned over the centre of the rear non-steerable axle of the tractor, the directions of the axles of all semitrailer wheels should intersect with this axis at a single point $\mathrm{O}_{2}$, thereby defining an instant turning centre of the semitrailer. When all of the semitrailer's wheels are steerable, this point can practically take any position on the axis of the non-steerable axle of the tractor, limited solely by the possible steering angles of the semitrailer wheels. A straight line projected from this point perpendicularly to the axis of the semitrailer sets the apparent non-steerable axle of the semitrailer. The variable position of the instant turning centre of the semitrailer means that this axle changes its position, approaching or moving away from the kingpin.

In the case of semitrailers having a real axle with non-steerable wheels, the instant turning centre is located at the point of intersection of the axis of this axle with the axis of the non-steerable axle of the tractor. As shown in the diagram, during the execution of a turn by a combination vehicle, the points $O_{1}$ and $O_{2}$ of the instant turning centres of the tractor and the semitrailer tend to diverge. However, when negotiating a turn, the point of the instant turning centre of the semitrailer fol- lows the point of the instant turning centre of the tractor, and in a longer turn it can 'catch up', which may lead to unification of the two points. The above geometric relations for wheels turning without skidding should characterize properly functioning steering mechanisms of the tractor and the semitrailer. The mathematical description of these relations was used to develop a special spreadsheet for the theoretical study of the manoeuvrability of the trailer.

\section{Spreadsheet for the Theoretical Study of the Manoeuvrability of the Trailer}

The numerical spreadsheet developed facilitates analysis of the movements of the wheels of the tractor-semitrailer combination with the assumption that they roll without skidding. It calculates the steering angles of the semitrailer wheels, as well as rear out-swinging and corner cutting during turning. The input data entered into the spreadsheet include the geometric parameters of the tractor-semitrailer combination and the bend (Fig. 3).

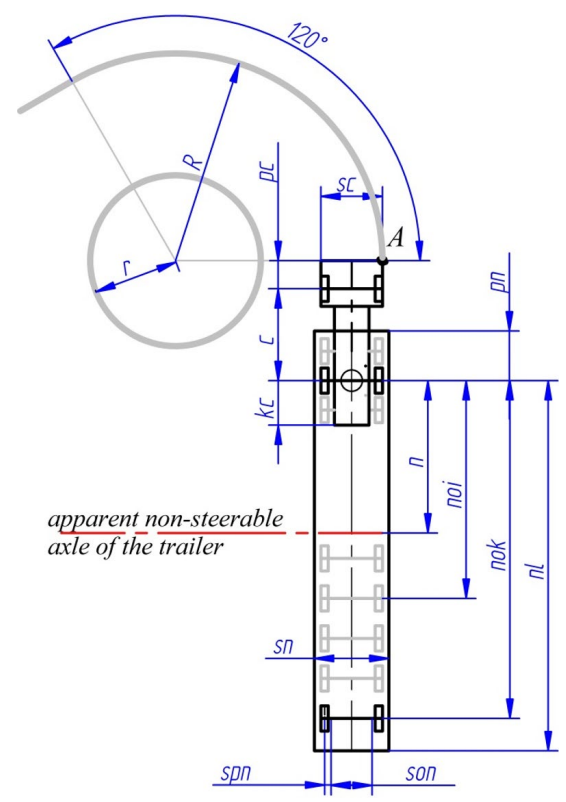

Fig. 3. Primary geometric parameters in the tractorsemitrailer combination manoeuvrability spreadsheet

Tractor parameters:

- $p c$ - distance from the front bumper to the axle of the tractor's steerable front wheels;

$-c$ - distance from the front steerable axle to the rear non-steerable axle of the tractor;

- $k c$-distance from the rear non-steerable axle to the tractor's rearmost point;

- $s c$ - width of the tractor.

Semitrailer parameters:

- nok - distance from the kingpin to the last steerable axle of the semitrailer;

- noi - distance from the kingpin to the axle number $i$ of the semitrailer;

- $n l$ - distance from the kingpin to the rear bumper; 
- $p n$ - distance from the front of the semitrailer to the kingpin;

- sn - width of the semitrailer;

- son - distance between the stub axles of steerable axle wheels;

- spn - radius swept by semitrailer wheels.

Bend parameters include inner $r$ and outer $R$ radius as well as the angle of the bend curve. Because the aim of the simulations presented was to test the manoeuvrability of the non-standard large size semitrailer according to TÜV recommendations (Richtlinien für die Erteilung... 1993), the value of these parameters were adjusted to the length of the tractor-semitrailer combination (Table 1).

In the first version of the program, parameter $n$ specifying the distance of the non-steerable axle of the trailer from the kingpin was also introduced as an input datum. Initial calculations revealed that the greater the value of $n$, the greater the corner cutting, while a decrease in $n$ increases trailer out-swinging in the first phase of the turn. Thus, to ensure both the out-swinging and corner cutting at the lowest possible level, the value of $n$ should be changed during negotiation of the bend and should be related to the articulation angle between the tractor and the semitrailer in such a way that it decreases together with the increase of the articulation angle. Of course, the non-constant value of $n$ means that all the trailer axles have to be steerable ones (it is not possible to move a real rigid axle forward and backward in a real trailer).

Taking this into account, in the final version of the program parameter $n$, now specifying the distance of the apparent non-steerable axle from the hitching point, was related to articulation angle $\gamma$ between the tractor and the semitrailer (Fig. 2) by the equation:

$$
n=a \cdot \gamma^{k}+b
$$

where: $a, b$, and $k$ are coefficients of the equation, which are introduced into the program as input data.

Applying such relation made the program more universal because it enables different relations between $n$ and $\gamma$ to be tested, including constant $n(k=0)$.

In the mathematical model it is assumed that point $A$ located in the right corner of the front bumper of the tractor moves along the curve representing the right curb of the road (Figs 3 and 4). Calculations in the program are executed step by step with the elementary step corresponding to the constant increment in the position of the semitrailer on turn $p$. The value of position $p$ is determined as the value of the displacement of point $A$ along the right curb of the road, measuring it from the start of the turn. The length of the calculation step can be set. In the case of the calculation presented, the elementary increase in $p$ corresponded to an angular movement of one degree on the circular arc of the bend.

In order to enable the simulation of manual steering of semitrailer wheels during a turn (it is planned that the steering system of the new semitrailer will enable manual steering at low speeds), a correction of factor $b$ was made possible at any position of the semitrailer on turn $p$. After executing the calculations for a given value of $b$, it is possible to enter a new value of $b$ corresponding to a chosen value of $p$, and then calculations are executed from that position of semitrailer on turn $p$. The new value of $b$ can be entered for any $p$ as many times as desired.

Results of calculations for different values of the individual coefficients of the equation provided information on their impact on the correctness of the trailer's turn and permitted determination of the most favourable relationship $n(\gamma)$ allowing optimum negotiation of turns with a small radius and narrow road surface. Realization of the chosen relationship will be a task for the future steering system of the semitrailer. A command steering system, probably supported with some active elements, is planned to be used in the designed semitrailer.

The results of simulations are available as data series and are shown in the form of a visualization of the tracks of semitrailer wheel movement, against the background of an outline of the curbs on the bend (Fig. 4). Trajectories of the displacement of the rear right corner of the semitrailer (5), indicating the furthermost point of semitrailer swing-out (6), and the displacement of the point on the semitrailer which is closest to the centre of the bend (7), indicating the point of closest approach (8), are plotted. The visualisation also shows the articulation angle between the semitrailer and the tractor and the turning angles of the trailer's two rearmost wheels (Fig. 4). Trajectories and turning angles of the wheels of the additional $i$ axle could optionally also be shown, as in further figures.

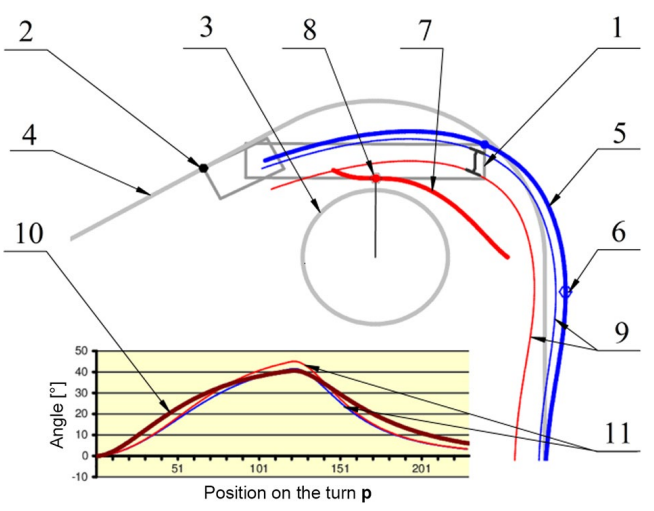

Fig. 4. A visualization of the results of spreadsheet simulation: 1 - an outline of the tractor-semitrailer combination; 2 - point $A$ of the tractor's front bumper; 3 - roundabout island; 4 right curb of the road; 5 - trajectory of the displacement of the rear right corner of the semitrailer; 6 - furthermost point of trailer out-swinging; 7 - trajectory of the displacement of the point on the trailer closest to the centre of the bend; 8 - point of closest approach to the centre of the bend; 9 - trajectories of the right and left rearmost wheels of the semitrailer; $10-$ articulation angle between semitrailer and tractor; 11 - steering angles of the semitrailer's two rearmost wheels (right and left) 


\section{Analysis of the Behaviour of a Multi-Axial Semitrailer at a Bend}

The analyses were conducted for the geometric data corresponding to the parameters of the designed semitrailer and TÜV requirements (Richtlinien für die Erteilung... 1993).

Since the semitrailer's length and width were adjustable and it was assumed that the semitrailer should meet the TÜV regulations (Richtlinien für die Erteilung... 1993) in all semitrailer-tractor configurations, minimum and maximum lengths and widths were considered in the first stage of the simulations. The geometric parameters of the tractor and the semitrailer used in the analysis are summarized in Table 2.

Table 2. The geometric parameters of the tractor-semitrailer combination tested for steering behaviour in a bend

\begin{tabular}{cc|cc}
\hline \multicolumn{2}{c|}{ Tractor } & \multicolumn{2}{c}{ Semitrailer } \\
\hline$p c$ & $1.44 \mathrm{~m}$ & $p n$ & $1.40 \mathrm{~m}$ \\
\hline$c$ & $3.06 \mathrm{~m}$ & $n o k$ & $15.74+2.00 \mathrm{~m}$ \\
\hline$k c$ & $1.40 \mathrm{~m}$ & $n l$ & $16.54+2.00 \mathrm{~m}$ \\
\hline$s c$ & $3.07 \mathrm{~m}$ & $s n$ & $2.55+0.55 \mathrm{~m}$ \\
\hline \multirow{2}{*}{} & \multicolumn{2}{c}{$s o n$} & $1.19 \mathrm{~m}$ \\
\cline { 3 - 4 } & & $s p n$ & $0.41 \mathrm{~m}$ \\
\cline { 3 - 3 } & & &
\end{tabular}

The aim of the first stage of the simulations was to check if the semitrailer equipped with one non-steerable axle could meet the requirements. Thus the first tests of the behaviour of the semitrailer at a bend were carried out with the assumption that the value of parameter $n$ remained constant throughout the whole turning manoeuvre. This corresponded to the semitrailer with one non-steerable axle located in the distance $n$ from the kingpin. Different values of parameter $n$ were tested to determine the range for which the semitrailer would meet the criteria described in Table 1 . This was achieved for $n$ in the range of 8.38-10.62 $\mathrm{m}$ in the case of nonextended semitrailer (basic values of length and width presented in Table 2) and for $n$ in the range of 10.78$10.94 \mathrm{~m}$ in the case of extended semitrailer (length and width enlarged by 2 and $0.55 \mathrm{~m}$, respectively). The range of permissible values of $n$ for the extended semitrailer was very narrow. For $n=10.94 \mathrm{~m}$, the semitrailer turned approaching the centre of the bend at a distance of $6 \mathrm{~m}$, just equal to the inner radius, while its maximum outswinging in the first stage of the turning manoeuvre, amounting to $1.33 \mathrm{~m}$, was only slightly lower than the allowable $1.4 \mathrm{~m}$. On the other hand, for $n=10.78 \mathrm{~m}$, the out-swinging of the trailer during the turn was equal to the permissible value $(1.4 \mathrm{~m})$ and the distance from the centre of the bend was only $11 \mathrm{~cm}$ greater than the allowable $6 \mathrm{~m}$.

Nevertheless, the results obtained meant that the trailer with a non-steerable axle placed at a distance of between 8.78 to $8.94 \mathrm{~m}$ from the kingpin would meet the requirements (Fig. 5). The given distance is for a non-extended trailer; this distance increases together with increases in the length of the trailer, because the axle would be fixed to the rear part of the semitrailer. Thus, in the case of a trailer lengthened by $2 \mathrm{~m}$, this axle should be at a distance of between 10.78 to $10.94 \mathrm{~m}$ (Fig. 6).

Unfortunately, analyses of the design revealed that it would not be possible to achieve the assumed length of the low platform if the axle line had been placed in such distance from the kingpin. For design reasons, this distance should be bigger than $9.5 \mathrm{~m}$. That meant that all the axles of the semitrailer should have steerable wheels.

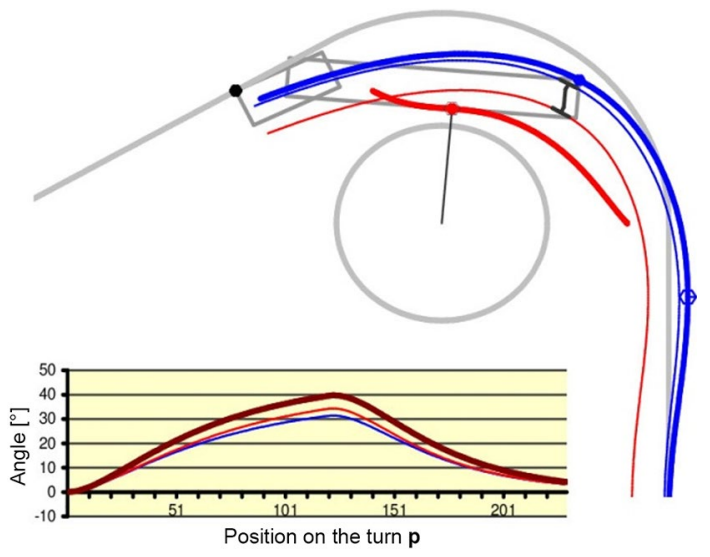

Fig. 5. Negotiating a turn by a non-extended semitrailer for a fixed position of the non-steerable axle at $n=8.86 \mathrm{~m}$ $(s n=2.55 \mathrm{~m}$; length of the combination $l c=21.04 \mathrm{~m}$; maximal swing out $\operatorname{Smax}=1.18 \mathrm{~m}$; minimal inner radius $R \min =7.65 \mathrm{~m}$; max steering angle of the rear inner wheel $\delta=34.33^{\circ}$ )

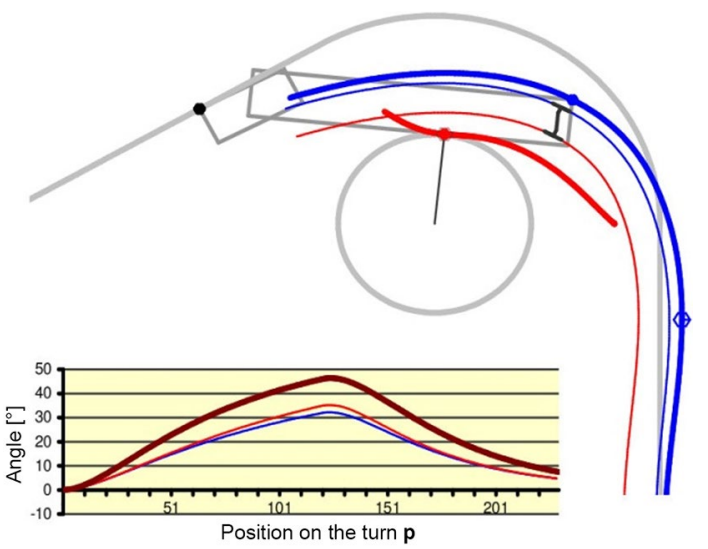

Fig. 6. Negotiating a turn by a maximally extended semitrailer for a fixed position of the non-steerable axle at $n=10.86 \mathrm{~m}$ $(s n=3.1 \mathrm{~m} ; l c=23.04 \mathrm{~m} ; \operatorname{Smax}=1.37 \mathrm{~m} ; R \min =6.06 \mathrm{~m}$; $\left.\delta=35.21^{\circ}\right)$

The length of the combination with a maximally extended semitrailer only slightly exceeded $23 \mathrm{~m}$ and the requirements concerning maneuverability were less restrictive than for a $23 \mathrm{~m}$ or less combination (Table 1). Because it was planned that the length of the low platform would be adjusted by many steps (not only two: unextended and maximally extended), the length of the real combination may be equal or slightly lower than $23 \mathrm{~m}$ and the semitrailer should meet the requirements in such a case as well. Taking this into account, the 
length of the semitrailer in the simulations was adjusted in such a way that the length of the combination was equal to $23 \mathrm{~m}$. For this length, it was checked if the semitrailer equipped with all steerable axles and fixed position of the apparent non-steerable axle $(n=$ const) was able to meet the requirements. In such a case the steering mechanisms could be practically the same as in the case of one real non-steerable axle, only wheels of one more axle have to be steered (it should be noticed that from the point of view of a steering system realizing the strategy of constant $n$, the angles of the steered wheels should be the same, regardless of the existence of a real rigid axle at distance $n$ ).

Results of the simulations revealed that the $23 \mathrm{~m}$ long combination was not able to negotiate the regulation bend at constant position of apparent non-steerable axle even if the semitrailer was equipped with all steerable axles. For $n$ values greater than $10.21 \mathrm{~m}$ corner cutting was too big, whereas for $n$ values smaller than $10.75 \mathrm{~m}$, out-swinging was too big. That meant that for $n$ from a range between 10.21-10.75 m both corner cutting and out-swinging exceeded permissible values (Fig. 7).

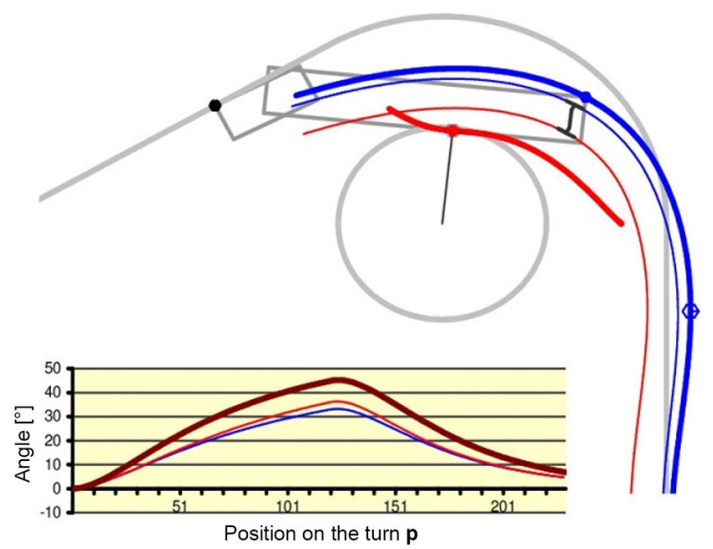

Fig. 7. Negotiating a turn by a $23 \mathrm{~m}$ long combination for a fixed position of the non-steerable axle at $n=10.5 \mathrm{~m}(s n=3.1 \mathrm{~m}$; $\left.l c=23 \mathrm{~m} ; S \max =1.51 \mathrm{~m} ; R \min =6.31 \mathrm{~m} ; \delta=36.28^{\circ}\right)$

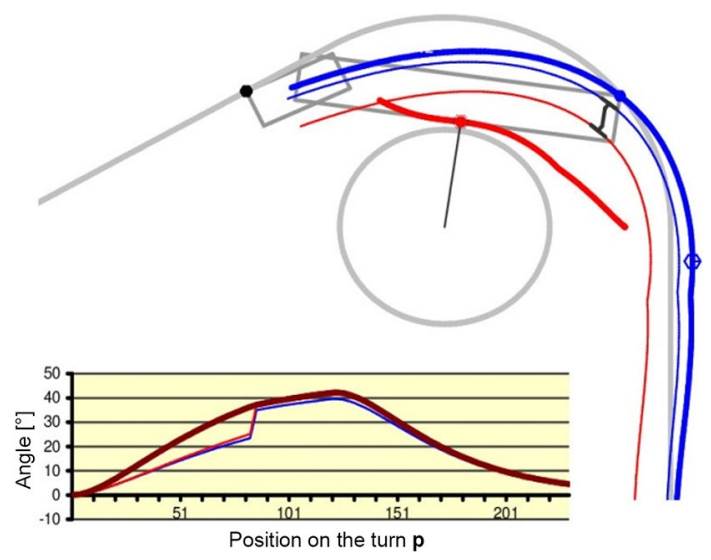

Fig. 8. Negotiating a turn with manual override of steering angle in the middle of the band: $n=11 \mathrm{~m}$ for $p \leq 82$ and $n=9 \mathrm{~m}$ for $p>82(s n=3.1 \mathrm{~m} ; l c=23 \mathrm{~m}$; $S \max =1.36 \mathrm{~m}$; $R \min =7.1 \mathrm{~m} ; \delta=42.95^{\circ}$ )
It was then checked if the combination would be able to meet requirements with manual steering. Such a possibility is allowed by the TÜV recommendation (Richtlinien für die Erteilung... 1993) for combinations whose length is greater than $20 \mathrm{~m}$. For this purpose the value of parameter $n$ was gradually changed during the negotiation of the bend. The results of the simulations showed that the combination would be able to meet the requirements with manual steering. In the example shown in Fig. 8, $n=11 \mathrm{~m}$ was applied in the first phase of the turn, and when the semitrailer had negotiated half of the turn, $n$ was abruptly decreased to $9 \mathrm{~m}$. It can be observed that in this case the out-swinging of the trailer and corner cutting were reduced, but the value of the steering angle of the wheels increased.

However, Wielton Company wanted the semitrailer to meet the regulations without manual steering. Thus, the tests in which the position of apparent non-steering axle was changing during the negotiation of the bend and was related to the value of articulation angle $\gamma$ between tractor and semitrailer by a functional dependency (1) were made.

The results of the simulations carried out up to now indicated that if the $23 \mathrm{~m}$ long tractor-semitrailer combination meets the requirements, it will also be met by a shorter and a slightly longer one (less rigorous requirements - Table 1). Thus, the further trials were conducted for a $23 \mathrm{~m}$ long combination and a maximally widened semitrailer.

The simulations were run for different values of parameters $a, b$ and $k$. The ranges of values of parameters $a$ and $b$ for which the combination satisfied the needs for $k=1$ or $k=2$ are shown in Fig. 9. The results showed that the greater the value taken by $k$ or the smaller the value taken by $a$, the better the maneuverability of the combination (the combination needing less road space

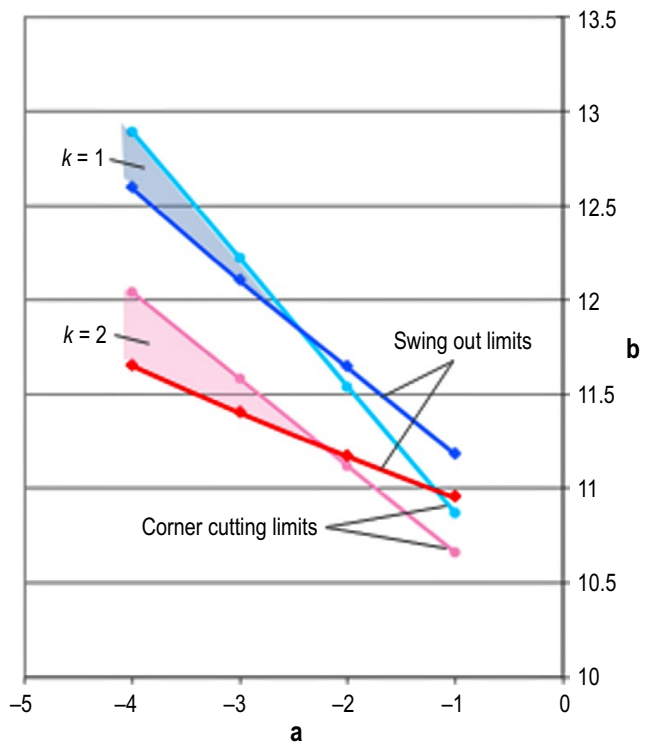

Fig. 9. Areas of values of coefficients $a$ and $b$ for which a $23 \mathrm{~m}$ long combination meets the requirements in the case of linear $(k=1)$ or quadratic $(k=2)$ relationship between position of apparent non-steerable axle $n$ and articulation angle $\gamma$ 
to negotiate the bend), but at the same time the maximum steering angle of the semitrailer wheels increases. However tests carried out revealed that the benefits of using of a quadratic ( $k=2$, Fig. 9) or a cubic function $(k=3)$ are not significant.

Taking into account the pursuit of small steering angles of the semitrailer wheels and possibility of application, the linear relationship between position of the apparent non-steerable axle $n$ and articulation angle $\gamma$ was recognized as the most favorable. In the case of the $23 \mathrm{~m}$ long combination, the steering system of the semitrailer should change $n$ according to the dependence: $n(\gamma)=-2.5 \cdot \gamma+11.88$ to ensure the smallest maximum steering angles. For such a dependence $n(\gamma)$ the maximum out-swinging and corner cutting by the combination were equal to the permissible values, and maximum wheel steering angle was equal to $39.18^{\circ}$.

Subsequent simulations confirmed that a semitrailer equipped with the steering mechanism implementing the linear dependence $n(\gamma)$ would be able to satisfy the TÜV requirements (Richtlinien für die Erteilung... 1993) for all possible combinations of its length and width without needing to use manual steering. Figs 10 and 11 present the results of simulations for the shortest and longest semitrailer. The combination of tractor and the shortest (but widened) semitrailer negotiated the bend by a wide margin (Fig. 10). The maximally extended semitrailer also remained safely inside the required limits (Fig. 11).

The reduction in the value of $a$ or applying a quadratic or cubic dependence (1) resulted in satisfying the requirements by a larger margin, but the steering angles of the wheels were bigger (Fig. 12). The increase in these angles makes the design of the axle more complex and forces a decrease in the width of the semitrailer frame, which is disadvantageous for the strength and stiffness of the frame. It was checked that in the case of the semitrailer investigated the greater the distance of a particular axle from the kingpin, the greater the maximum steering angles of the wheels. For example, in Fig. 11 the trajectories and steering angles of the wheels of the first

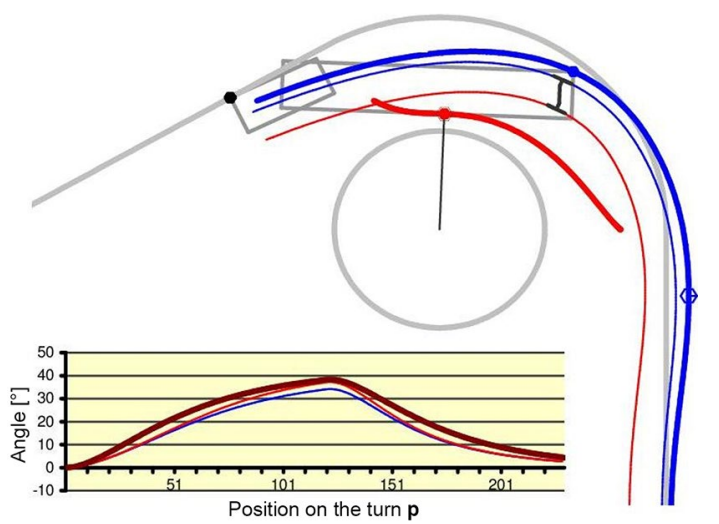

Fig. 10. Negotiating a turn by non-extended semitrailer assuming a linear relationship between $n$ and $\gamma: n=-2.5 \gamma+9.92$ $(s n=3.1 \mathrm{~m} ; l c=21.04 \mathrm{~m} ; \operatorname{Smax}=1.39 \mathrm{~m} ; R \min =7.64 \mathrm{~m}$; $\left.\delta=37.23^{\circ}\right)$

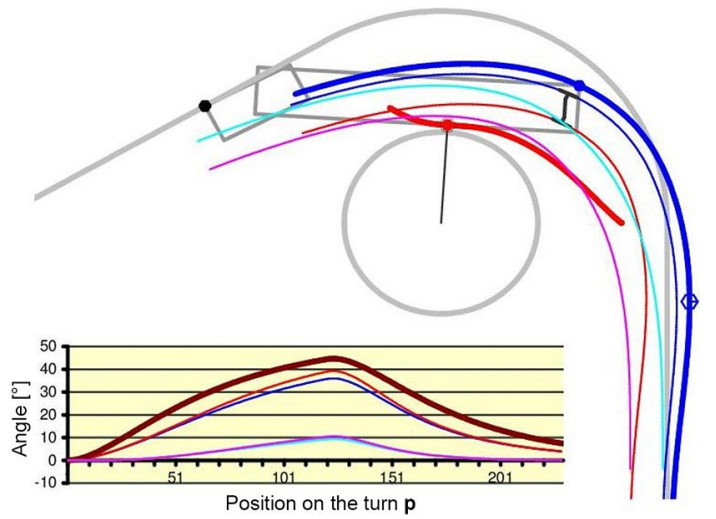

Fig. 11. Negotiating a turn by extended semitrailer assuming a linear relationship between $n$ and $\gamma: n=-2.5 \gamma+11.92$ $(s n=3.1 \mathrm{~m} ; l c=23.04 \mathrm{~m} ; S \max =1.39 \mathrm{~m} ; R \min =6.48 \mathrm{~m}$; $\delta=39.22^{\circ}$; trajectories and steering angles of wheels of the first semitrailer axle are also presented, max steering angle of the left wheel of the first axle is $10.51^{\circ}$ )

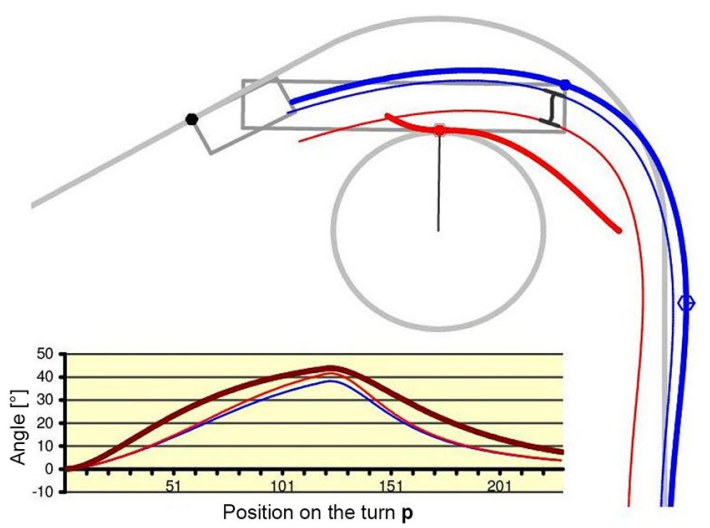

Fig. 12. Negotiating a turn by a $23 \mathrm{~m}$ long combination assuming a quadratic relationship between $n$ and $\gamma: n=-4 \gamma^{2}+11.8$ $(s n=3.1 \mathrm{~m} ; l c=23.04 \mathrm{~m} ; S \max =1.33 \mathrm{~m} ; R \min =6.64 \mathrm{~m}$; $\left.\delta=41.63^{\circ}\right)$

axle are additionally shown (it was assumed that the first axle is $6 \mathrm{~m}$ before the last one). So it was suggested to apply axles with different maximum steering angles. In the last axle line of the semitrailer - axles having maximum steering angles of $40^{\circ}$ should be used, while in the first line - axles having maximum steering angles of $12^{\circ}$ would be sufficient.

\section{Conclusions}

A spreadsheet for theoretical analysis of the behavior of a tractor-semitrailer combination was developed. A study on the possibility of meeting the TÜV regulations concerning maneuverability of a newly designed fiveaxle, extendable, large-sized semitrailer was performed with the use of the spreadsheet.

It was found that the semitrailer would not be able to satisfy the requirements if it were equipped with even one non-steerable axle. It would not be able to satisfy the needs if equipped with all steerable axles and a steering mechanism keeping the constant position of the apparent non-steerable axle either. 
The semitrailer at all possible combinations in its dimensions equipped with all steerable axles and a proper steering mechanism implementing the changes in the position of the apparent non-steerable axle as a function of the articulation angle between the tractor and the semitrailer would be able to negotiate a bend of a specified radius and road width.

A linear relationship between the position of the apparent non-steerable axle and the articulation angle allows the requirements to be fulfilled without the need to use manual steering. In such a case the maximum steering angles of the last axle wheels is equal to $39.2^{\circ}$, and the first axle wheels is only $10.5^{\circ}$. Taking into account the big difference and the bad influence of the bigger angles on the semitrailer design, the use of axles with different maximum steering angles is suggested.

Applying a quadratic or cubic relationship between the position of the apparent non-steerable axle and the articulation angle and/or smaller values of parameter a permits improvements in the maneuverability of the semitrailer (less road space necessary to negotiate the bend), however it results in the larger steering angles of the wheels.

\section{References}

Berjoza, D. 2008. Research in kinematics of turn for vehicles and semitrailers, in Proceedings of 7th International Scientific Conference on Engineering for Rural Development, 29-30 May 2008, Jelgava, Latvia, 177-182.

Bortoni-Anzures, L.; Herrera-Ruiz, G.; Fabela-Gallegos, M. J.; Hernandez-Jimenez, R.; Martinez-Madrid, M. 2008. Experimental study of the maneuverability of a testing trailer with a steering axle at low speed maneuvers, SAE Technical Paper 2008-01-2705.

http://dx.doi.org/10.4271/2008-01-2705

Dębski, H.; Koszałka, G.; Ferdynus, M. 2012. Application of fem in the analysis of the structure of a trailer supporting frame with variable operation parameters, Eksploatacja $i$ Niezawodność - Maintenance and Reliability 14(2): 107114.

Ding, X.; Mikaric, S.; He, Y. 2013. Design of an active trailersteering system for multi-trailer articulated heavy vehicles using real-time simulations, Proceedings of the Institution of Mechanical Engineers, Part D: Journal of Automobile Engineering 227(5): 643-655.

http://dx.doi.org/10.1177/0954407012461223

Dixon, J. C. 2009. Suspension Geometry and Computation. Wiley. $434 \mathrm{p}$.

EC. 1996. Council Directive 96/53/EC of 25 July 1996 Laying Down for Certain Road Vehicles Circulating within the Community the Maximum Authorized Dimensions in National and International Traffic and the Maximum Authorized Weights in International Traffic. 17 p. Available from Internet: http://eur-lex.europa.eu/legal-content/EN/TXT/ $\mathrm{PDF} /$ ?uri=CELEX:31996L0053\&rid=2

EU. 2012. Commission Regulation (EU) No 1230/2012 of 12 December 2012 Implementing Regulation (EC) No 661/2009 of the European Parliament and of the Council with Regard to Type-Approval Requirements for Masses and Dimensions of Motor Vehicles and Their Trailers and Amending Directive
2007/46/EC of the European Parliament and of the Council. Available from Internet: http://eur-lex.europa.eu/legalcontent/EN/ALL/?uri=CELEX:32012R1230

Gidlewski, M. 2011. Opportunities to investigate the steering system for improvement of truck driving properties under critical road conditions, Archives of Transport 23(3): 285-290.

He, Y.; Islam, M.; Webster, T. 2010. An integrated design method for articulated heavy vehicles with active trailer steering systems, SAE International Journal of Passenger Cars - Mechanical Systems 3(1): 158-174.

http://dx.doi.org/10.4271/2010-01-0092

Hussain, K.; Stein, W.; Day, A. J. 2005. Modelling commercial vehicle handling and rolling stability, Proceedings of the Institution of Mechanical Engineers, Part K: Journal of Multibody Dynamics 219(4): 357-369.

http://dx.doi.org/10.1243/146441905X48707

Kharrazi, S.; Lidberg, M.; Fredriksson, J. 2013. A generic controller for improving lateral performance of heavy vehicle combinations, Proceedings of the Institution of Mechanical Engineers, Part D: Journal of Automobile Engineering 227(5): 619-642. http://dx.doi.org/10.1177/0954407012454616

Koszałka, G.; Olejnik, K. 2012. Proposal of the semi-trailer additional lighting reducing road traffic risk, Scientific Journals of the Maritime University of Szczecin - Zeszyty Naukowe Akademii Morskiej w Szczecinie 31: 122-127.

Liu, P.; Caroux, J. 2011. Steer laws for steerable trailer axles to reduce tire wear, SAE International Journal of Commercial Vehicles 4(1): 31-39. http://dx.doi.org/10.4271/2011-01-2153

Odhams, A. M. C.; Roebuck, R. L.; Jujnovich, B. A.; Cebon, D. 2011. Active steering of a tractor-semi-trailer, Proceedings of the Institution of Mechanical Engineers, Part D: Journal of Automobile Engineering 225(7): 847-869.

http://dx.doi.org/10.1177/0954407010395680

Ormezowski, J. 2008. Kinematics analysis of a steering linkage, The Archives of Automotive Engineering - Archiwum Motoryzacji 41(2): 145-156. (in Polish).

Percy, A.; Spark, I. 2012. A numerical control algorithm for a Bdouble truck-trailer with steerable trailer wheels and active hitch angles, Proceedings of the Institution of Mechanical Engineers, Part D: Journal of Automobile Engineering 226(3): 289-300. http://dx.doi.org/10.1177/0954407011417355

Rangavajhula, K.; Tsao, H.-S. J. 2008. Command steering of trailers and command-steering-based optimal control of an articulated system for tractor-track following, Proceedings of the Institution of Mechanical Engineers, Part D: Journal of Automobile Engineering 222(6): 935-954. http://dx.doi.org/10.1243/09544070JAUTO501

Richtlinien für die Erteilung von Ausnahmegenehmigungen nach $\$ 70$ StVZO für bestimmte Arbeitsmaschinen und bestimmte andere Fahrzeugarten (Richtlinien zu $\$ 70$ StVZO). 1993. Bonn, den StV 13/36.39.21-00. 40 S. (in German).

Stokłosa, J.; Koszałka, G.; Gil, L. 2012. Analiza sił w elementach mocujących ładunki na pojazdach samochodowych, Advances in Science and Technology: Research Journal 12: 94-100 (in Polish).

Tabatabaei Oreh, S. H.; Kazemi, R.; Azadi, S. 2012. A new desired articulation angle for directional control of articulated vehicles, Proceedings of the Institution of Mechanical Engineers, Part K: Journal of Multi-body Dynamics 226(4): 298-314. http://dx.doi.org/10.1177/1464419312445426 